\title{
Barriers and Challenges to the Sustainability Requirements Implementation in Public Procurement of Engineering Works and Services
}

\author{
Clézio Thadeu de Souza Dutra, Ubiratan Rohan, Robson Rosa Branco, \\ Christine Kowal Chinelli, Alexandre Jose Vianna Barbosa de Araujo, \\ Carlos Alberto Pereira Soares
}

Graduate Program in Civil Engineering, Fluminense Federal University, Niterói, Brazil

Email: cleziodutra@poscivil.uff.br, ubiratanrohan@id.uff.br, robson.branco@gmail.com, ckchinelli@gmail.com, ava.2000@hotmail.com, carlossoares.uff@gmail.com

How to cite this paper: de Souza Dutra, C.T., Rohan, U., Branco, R.R., Chinelli, C.K., de Araujo, A.J.V.B. and Soares, C.A.P. (2017) Barriers and Challenges to the Sustainability Requirements Implementation in Public Procurement of Engineering Works and Services. Open Journal of Civil Engineering, 7, 1-13.

https://doi.org/10.4236/ojce.2017.71001

Received: November 15, 2016

Accepted: January 16, 2017

Published: January 19, 2017

Copyright (C) 2017 by authors and Scientific Research Publishing Inc. This work is licensed under the Creative Commons Attribution International License (CC BY 4.0).

http://creativecommons.org/licenses/by/4.0/

\begin{abstract}
The environmental damage arising from the construction and engineering services was responsible for the appearance of several norms and resolutions regulating and directing the sector's performance. In this article, we research how professionals with experience in public bids assess the difficulty degree of the implementation of those requirements and how they assess the environmental legislation regarding the protection and conservation of the environment, impact on costs, deadlines and the solution to environmental problems. The results show that industry professionals consider as "high" the level of difficulty to implement the addressed sustainability requirements, and that the Brazilian environmental legislation does not comply with its environmental protection role, increases the possibility of delays and costs of projects and services and hampers the emergence of solutions that could solve environmental problems.
\end{abstract}

\section{Keywords}

Environmental Sustainability Requirements, Environmental Protection, Sustainable Procurement, Construction and Engineering Services

\section{Introduction}

Products and construction services require productive activities that generate strong environmental impacts. The construction industry is singled out by the 
International Council for Building (ICB) as the human activities sector that consumes more natural resources and uses energy in an intensive way, generating significant environmental impacts [1].

"Construction has been accused of causing environmental problems ranging from excessive consumption of global resources both in terms of construction and building operation to the pollution of the surrounding environment" [2].

The various phases of construction works interact extensively with the environment, and can result in vegetation removal, soil movement (in the Earthmoving stage), consumption of natural resources for the implementation of concrete elements and waste generation associated with various activities [3].

According to Brammer and Walker [4] "the environmental impact of the construction industry is probably larger in developing countries than it is in develop ones, because developing countries are virtually still under construction, and that they have a relatively low degree of industrialization, making the construction industry one of the biggest sectors impacting on the biophysical environment."

The construction model practiced in Brazil causes environmental damage due to the exhaustive usage of non-renewable raw material, the consumption of large amounts of energy, and it is a great source of waste, thereby causing environmental degradation [5] [6].

This context makes the insertion of more sustainable practices in the construction and building services an item that is usually present in sustainability agendas. In this regard, the movement towards a more sustainable engineering has the government as a key agent, seeing that it is a major contractor of engineering works and services.

The State has an essential role in building and achieving sustainability, acting as the major contractor of goods and services, being able to modify the marketing parameters, inserting and charging for the suppliers to adopt an economic production eco-efficient [7] [8].

Considering the size and cost of public procurement, sustainable public procurement has the ability to play an important role in providing social benefits. [4].

Sustainable procurement enables public institutions to meet the needs of goods, services and works considering not only the benefits for the organization, society and the economy, but also the minimization of environmental damage [9] [10] [11]. Therefore, the government, as well as ensuring the lowest price in their contracts, also has the duty to mitigate environmental impacts through the enforceability of sustainability requirements that must be observed by those who participate in bidding processes.

Sustainable procurement has been identified as one major alternative and some researchers have identified that in the future, customer demand and business competition will be the dominant reason for driving environmentally sustainable issues [12]. 
The term "Sustainable Procurement" is used to represent the bidding process that incorporates environmental and social aspects in all procurement stages in order to reduce impacts on human health, the environment and human rights.

As of January 2010, the Federal Government began to demand more effectively the establishment of criteria for environmental sustainability in the contracting of services or works by the Federal Public Administration, in accordance with the requirements of the institutions responsible for standardization and control.

The inclusion of compliance with the environmental requirements established by the main Brazilian institutions responsible for standardization and control in the bidding process meant a significant progress in the qualification of technical requirements and objectives to be used by both institutions responsible for the bidding process and by the inspection bodies.

The literature suggests that the incorporation of sustainability requirements is fraught with barriers/challenges. The main barriers and challenges found in the literature review are:

a) Financial; Informational; Legal; Managerial/structural; Political/cultural; Product/quality; Priority [4].

b) Absence of internal management structures; Lack of social drive; Low technical and management capacity; Low multi-stakeholder approach; Low stakeholder education; Lack of understanding of the SP concept; Lack of basic education about SP; The absence of governmental interest in ensuring the promotion of SP; Lack of political will; Corruption existing among procurement practitioners; Lack of capacity of small scale suppliers/contractors; Higher initial associated costs [11].

c) Difficulties in inserting environmental issues in a bid; Lack of support from senior management team; Lack of support from other staff and workers; Lack of roadmap or strategy; Lack of management commitment; Other procurement targets; Contractors abilities; Lack of knowledge/skills; Resource limitations; Poor communication; Weak processes; Cost reduction focus; Implementation costs are too high; Lack of training; Complex documentation processes/procedures; Loss of competitive edge; Focus on reducing cost at expense of environmentally; Resistance of employees; friendly practices; Lack of contractor awareness; Costs of improvement are too high; Accounting methods limit green reporting; Pressure for lower prices environmental; Conflict with assembly's objective; Lack of understanding of how to insert issues in contracts; Reluctance to change from traditional practices; Shortage of personnel; Lack of tailor-made training; Lack of support from suppliers/contractors; Lack of government guidance/support; Volume of sustainability information; Lack of supplier commitment; Language and cultural differences; Unwilling to exchange; Limiting standards; Competitive pressures; Lack of knowledge in the industry; Inhibits innovation; Unwilling to exchange information; Contractors desire for lower prices; Poor contractor/supplier commitments [12]. 
d) Lack of Building Codes and Regulation; Lack of incentives; Higher investment cost; Risk of investment; Higher final cost; Lack of public awareness; Lack of demand; Lack of strategy to promote sustainable construction; Lack of design and construction team; Lack of expertise; Lack of professional knowledge; Lack of database and information; Lack of technology; Lack of government support; Lack of a measurement tool; Increased documentation; Extensive pre-contract planning; Change resistance; Lack of training; Lack of cooperation [13].

e) Complexity of the certification process and the work execution; Additional costs with the certification, consulting and sustainable construction; Difficulty in obtaining supplies; Difficulty to hire and train staff; Focus on short-term entrepreneur; It takes longer to approve and design; The buyer does not pay additional amount; Few existing research in the country; Little knowledge on the subject; Little interest from the senior management; Low investment in research; Little or no public encouragement [14].

f) Lack of funding, restrictions on expenditure and reluctance to incur higher capital cost when needed; Lack of awareness, understanding, information, commitment and demand; Insufficient/inconsistent policies, regulations, incentives and commitment by leadership; Insufficient/confusing guidance, tools, demonstrations and best practice; Vagueness of definitions and diversity of interpretations; Separation between capital budget and operational budget; Lack of sufficient time to address sustainability issues; Lack of long-term perspective; General perception that addressing sustainability always; Leads to incurring greater capital cost; Resistance to change; Insufficient integration and link-up in the industry; insufficient research and development [15].

g) Cost concern, Lack of understanding of how to incorporate environmental issues into buying; Reluctance to change from traditional practices; Conflict with company's objective; Loss of competitive edge; Resistance of employees; Shortage of personnel; Lack of government support; Lack of knowledge in the industry [16].

h) Costs; Local nature of project; Lack of resources; Exposing poor environmental performance; Lack of information; Confidentiality; Fragmented industry; Small number of suppliers (poor competition); Scale of supply chain; Lack of industry-wide consistent environmental criteria; Procurement legislation; Clinical preference; Food culture; Inertia by project stakeholders; Supplier's (manufacturer) reluctance to change [17].

i) Cost price; Social and environmental considerations; Lack of a policy on sustainable procurement; Lack of support from the senior management on the implementation of the concept; Lack of skills and knowledge; lack of knowledge about sustainable procurement [18].

j) Cost Reduction; Efficiency; Outsourcing procurement; Sustainability legislation; Green credentials of goods/services; Availability of green products/ services; Clear legislation on green procurement; Ethical credentials of supplier; Carbon footprint; Ability to provide green data; Ethical credentials of products/services; Green credential of supplier [19]. 
According to Bramer [4] "research in sustainable procurement has tended to examine particular case studies, often taking a sectoral perspective by investigating how sustainability can be encouraged when buying from suppliers in specific industries".

Several researches were developed aiming to study of sustainable procurement initiatives in the building and construction [11]-[16] [20] [21].

Regarding the Brazilian environmental legislation, it is often brought as one of the most complete in the world. However, when considering the degrading activities, it has not been considered capable to achieve the objectives that justify its existence, especially in what it refers to the compatibility of economic growth with environmental protection [22], and when considering structural and conjunctural aspects of the Brazilian reality, many problems that result in a scarce implementation of environmental legislation are caused by a normative implementation failure, due to the inefficiency or to elements that mitigate their effectiveness [23].

In this article, we research how professionals with experience in public bids assess the degree of difficulty existent in the implementation of sustainability requirements that aim the protection and preservation of the environment in construction and engineering services, and how do they assess the environmental legislation concerning protection and conservation and the impact on cost, deadlines and the solution of environmental problems proceeding from theses works and services.

The main purpose is to collaborate to understand how-in practice-the sustainability requirements present in Brazilian legislation influence the bidding processes of engineering works and services. In this sense, it also broadens the discussion on the subject, since in Brazil there are no studies that approach the subject from the perspective of the engineering professionals who participate in these processes.

\section{Materials and Methods}

Initially, we carried out a field research in order to identify the perception of experts about the difficulty with which one can implement the main sustainability requirements foreseen in the Brazilian environmental legislation for sustainable procurement of engineering works and services:

1) Act with less impact on natural resources such as flora, fauna, air, soil and water;

2) Use materials, technologies and raw materials of local origin;

3) Use natural resources with environmentally regular origin;

4) Build projects with longer life and lower maintenance costs;

5) Use or produce innovations that reduce the pressure on natural resources;

6) Operate with greater efficiency in the use of natural resources such as water and energy.

Afterwards, dealing specifically with the Brazilian environmental legislation, we identified the agreement or disagreement of the respondents regarding the 
following statements on environmental legislation:

1) Adequately fulfill their protective role in the environment;

2) Increase the possibility of delays in projects and services;

3) Increase the costs of projects and services;

4) Hinders the emergence of solutions that solve environmental problems.

The data collection instrument was a questionnaire in which, to each one of the sustainability guidelines, respondents expressed the implementation difficulty, according to a Likert scale of five points-ranging from extremely difficult to no difficulty. For statements about environmental legislation respondents had to mark "yes" or "no".

A blank was made available so that respondents could comment on the surveyed items, if they thought necessary.

Engineers with experience in bidding process design and execution of engineering works and services were selected as respondents, characterizing an intentional sample. Thirty-five (35) experts were invited, and thirty (30) agreed to participate.

A pretest was conducted with two experts in order to identify possible doubts. In order to visualize and analyze the data of Likert type items, it was used the " $R$ " tool, a free software environment for statistical and graphical calculations, through the "R Likert Package" [24], which performs parametric tests in Likert scale [25] [26] [27] [28] [29], using the principles exposed by Speerschneider and Bryer [24] and Wakita et al. [30].

Using this tool, the reliability of the respondents and the data collection instrument was estimated by checking the internal consistency of the questionnaire through the Cronbach's Alpha coefficient [31], which enabled the measurement of the variance of the responses of each item and each respondent [32].

Cronbach's Alpha coefficient is one of the most important and widespread statistical tools in researches involving the elaboration of tests and its application, because it takes into account the variance attributed to the subjects and the variance attributed to the interaction between subjects and items, resulting in an index used to evaluate the magnitude in which the items of an instrument are correlated, making it possible to evaluate the correlations average between the items that are part of an instrument and the extent to which the factor measured is present in each item [33].

The " $R$ " environment was also used to calculate the distribution curves of each item referring to the results of the application of the IMS to the dimensions of Sustainability and to the potentialities and limitations, which served as a basis for the classification of items in function of the relevance and concordance degree and to the elaboration of graphics.

The data obtained using Likert's psychometric scale were subsequently converted into numbers ranging from 5 to 1 . In this manner, medians above 3 or $50 \%$ characterized high relevance or agreement.

For the analysis and interpretation of results it was also considered the comments made by respondents. 


\section{Results and Discussion}

\section{Process for Integrating Sustainability into the Construction Companies}

Table 1 and Figure 1 present the survey results regarding the difficulty with which the sustainability guidelines can be implemented, ranking them by the level of difficulty. In Figure 1, the values to the left of the bars represent low difficulty (sum of percentages of No Difficulty and Little Difficult), the right side of the bars represents high difficulty (sum of the percentages of Very Difficult and Extremely Difficult) and in the center of the bars the values refer to Moderate Difficulty.

The Cronbach alpha's value (0.80) was considered high [34], which proves the reliability of the data collection instrument and the respondents.

The modes of the answers related to the degree of difficulty are located on "High", and the medians are between "High" $(1,2,3,4,5)$ and "Moderate" (6), which shows a sense that most respondents tend to rank as high difficulty to implement all sustainability guidelines (Figure 2)

Table 1. Survey results: difficulty to implement sustainability guidelines.

\begin{tabular}{|c|c|c|c|c|c|c|}
\hline Difficulty level & Sustainability Guidelines & Low (\%) & Moderate (\%) & High (\%) & Mean & SD \\
\hline 1 & $\begin{array}{l}\text { Act with less impact on natural resources such as flora, fauna, } \\
\text { air, soil and water }\end{array}$ & 0 & 30 & 70 & 3.80 & 0.61 \\
\hline 2 & Build projects with longer life and lower maintenance costs & 10 & 27 & 63 & 3.80 & 0.96 \\
\hline 3 & Use materials, technologies and raw materials of local origin & 7 & 40 & 53 & 3.50 & 0.68 \\
\hline 4 & Use natural resources with environmentally regular origin & 13 & 37 & 50 & 3.43 & 0.82 \\
\hline 5 & $\begin{array}{l}\text { Use or produce innovations that reduce the pressure on } \\
\text { natural resources }\end{array}$ & 7 & 43 & 50 & 3.53 & 0.78 \\
\hline 6 & $\begin{array}{l}\text { Operate with greater efficiency in the use of natural resources } \\
\text { such as water and energy }\end{array}$ & 10 & 43 & 47 & 3.47 & 0.82 \\
\hline
\end{tabular}

Cronbach's alpha $=0.80$.

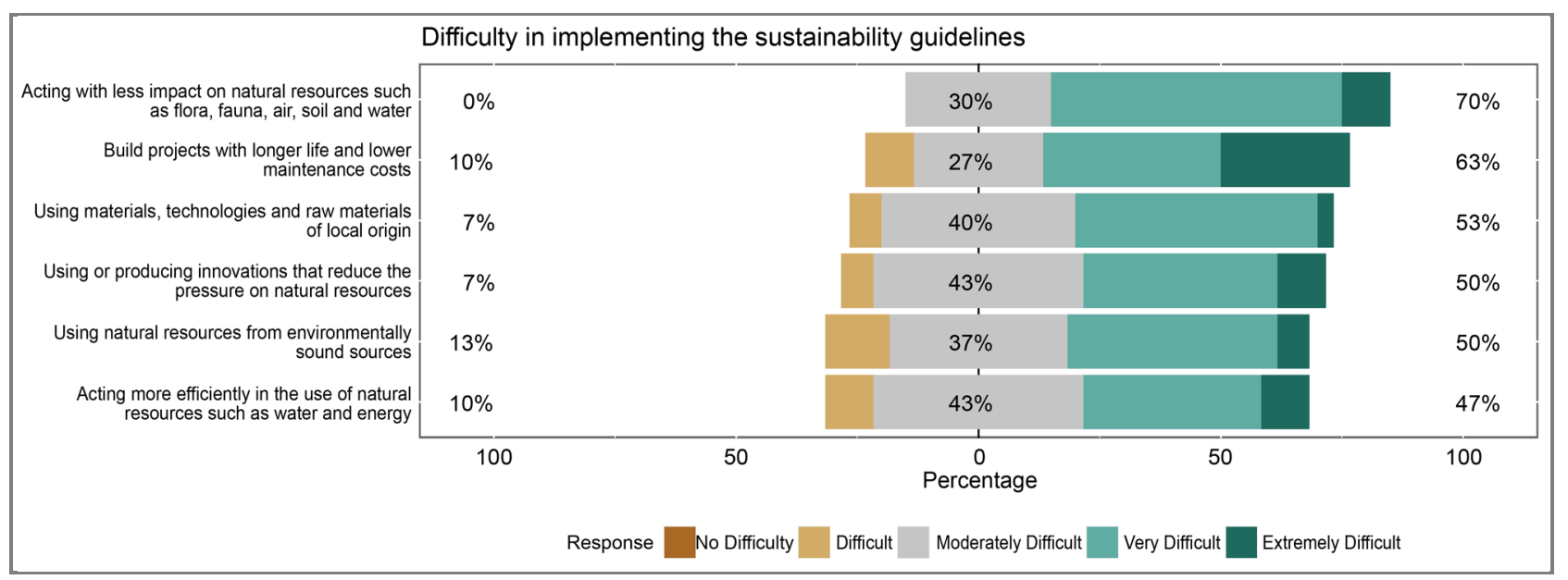

Figure 1. Survey results: difficulty to implement sustainability guidelines. 


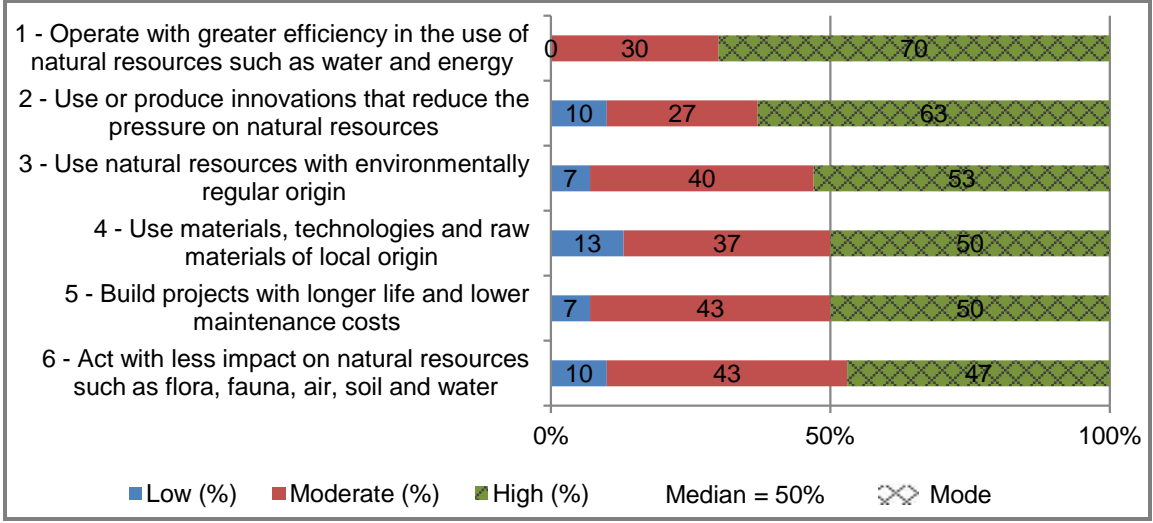

Figure 2. Survey results: mode and medians.

The main reasons used by respondents to mark the judgment as to the difficulties of implementing the sustainability guidelines were the rising costsmainly the cost of longer life materials and the cost of acquisition/production of more sustainable technologies; the difficulty of access to technology and more sustainable products and the lack of public policies and government incentives.

According to Adjarko et al. [12], cost concerns are the main obstacle for taking environmental issues into account in the procurement process.

The additional cost of sustainable construction consists on the cost difference between the sustainable and the conventionally produced version, taking into account all expenses (construction, design, certification, etc.), except for the terrain [35].

The fear of higher investment costs for sustainable buildings compared with traditional building [13], coupled with the fact that the economic results alone do not justify the additional investments [14], collaborate to a scenario where entrepreneurs find it difficult to develop more sustainable enterprises.

Moreover, depending on the minimum attraction rate established by each entrepreneur, the additional cost required by a venture can be considered a difference between its economic validation or not [14].

Regarding the difficulty of access to more sustainable technologies and products, a Brazilian civil construction chain has a low tradition of innovation [36], making it difficult to develop environmental technologies, which provide solutions to reduce the influx of substances, reduce the consumption of Energy and, like emissions, reuse by-products and minimize waste disposal problems [37].

Although the incentive for innovation is one of the virtues of sustainable bidding, Brazil lacks environmental public policies that adequately stimulate technological innovation, since the focus of these has usually been on the protection and conservation of natural resources.

What is seen is that governmental regulations and standards have collaborated to reduce the environmental impacts of engineering works and services. However, this legal apparatus has not been shown to be the most effective mean, nor has it offered sufficient and adequate incentives for innovation to occur as an addition to punctual solutions. In fact, the country lacks environmental policies 
that consider the entire innovation cycle and all actors involved.

The results referring to the adequacy of environmental legislation are summarized in Table 2.

The vast majority of respondents believe that environmental legislation does not adequately comply with its environmental protection function, increases the possibility of delays and cost of projects and services and hampers the emergence of solutions to environmental problems.

The vast majority of respondents believe that environmental legislation does not adequately comply with its environmental protection function, increases the possibility of delays and cost of projects and services and hampers the emergence of solutions to environmental problems.

The main reasons pointed by the experts are that the Brazilian environmental legislation needs to be improved because it is complex, bureaucratic and hinder the development of solutions/innovations; that punishments are ineffective and excessive, and the slowness in the analysis of licensing procedures are factors that impact deadlines and costs. Also, it was found a demand for technical guidance and training of the parties involved.

The Brazilian legislation applied to Civil Construction, especially regarding to building codes and technical norms of materials and processes, does not privilege and sometimes limits the investment in practices that allow more sustainable constructions. On the other hand, international experience shows that legal incentives can be important tools for the large-scale introduction of solutions that enable more sustainable construction [36].

The Brazilian environmental policy, in order to achieve harmony between exploration and preservation, uses regulatory forms to human action before nature, through fundamental principles established by law [38].

The challenges to be overcome by Brazilian environmental policy include lack of political will and priority, inter-sectoral fragmentation, legitimate participation, the inconsistency between laws and practices, and state ambiguity over private interests [39].

The justifications given by the respondents meet the research of national and international specialists who publish on the subject (Table 3), which shows that the barriers and challenges identified by the survey are not unique to the Brazilian reality.

Table 2. Adequacy of environmental legislation.

\begin{tabular}{lcc}
\hline \multicolumn{1}{c}{ Environmental legislation } & Yes (\%) & No (\%) \\
\hline Adequately fulfill their protective role in the environment; & 17 & 83 \\
Increase the possibility of delays in projects and services; & 97 & 3 \\
Increase the costs of projects and services; & 97 & 17 \\
Hinders the emergence of solutions that solve environmental problems & 83 \\
\hline
\end{tabular}

Kuder-Richardson $(\mathrm{KR}-20)=0.92$. 
Table 3. Barriers and challenges to the sustainability requirements implementation in public procurement of engineering works and services.

\begin{tabular}{ll}
\hline \multicolumn{1}{c}{ Barriers/Challenges } \\
\hline \multicolumn{1}{c}{ Survey } & \multicolumn{1}{c}{ Literature } \\
\hline Higher costs & {$[4][11]-[19]$} \\
$\begin{array}{l}\text { Insufficient or non-existent public policies and } \\
\text { government incentives }\end{array}$ & {$[4][11]-[16][18]$} \\
Inadequate legislation and procedures & {$[4][11][12][13][14][15][17][19][22]$} \\
$\begin{array}{l}\text { Need for training/technical guidance } \\
\text { Ineffective and excessive controls and punishments }\end{array}$ & {$[23]$} \\
$\begin{array}{l}\text { Slowness in the analysis of licensing procedures } \\
\text { Difficult access to technologies and more }\end{array}$ & {$[40][41]$} \\
sustainable products & {$[4][13][14][17]$} \\
\hline
\end{tabular}

Specifically on the inspection process, we consider that the Brazilian environmental legislation requires a considerably large oversight body to guarantee that the compliance of the standards established by governmental spheres can be properly monitored. Vaz [40] mentions the tiny number of taxation authorities, the continental size of the country and the existence of corruption as an example of factors that make the control actions one of the weakest points of the state.

As to the delay that licensing agencies face in the analysis of environmental license applications, Pedro [41] considers that this is not due to technical failure of those bodies, but the budgetary difficulties and the small number of available technicians.

\section{Conclusions}

The survey reveals that entrepreneurs tend to consider as "high" the difficulty to implement the main sustainability requirements of Brazilian environmental legislation for bidding processes of construction works and services.

It also acknowledges the tendency of entrepreneurs considering that the environmental legislation does not comply properly with its protective role, increases the possibility of delays and cost of projects and construction services and hampers the emergence of solutions that could solve environmental problems.

In several researches related to the theme, selected through literature review, the challenges and barriers identified are also present, which shows that they are not exclusive to the Brazilian reality.

The results point out the need to think of a more participatory environmental legislation development process, in which the demands of the construction industry can be discussed.

\section{References}

[1] Ministério do Meio Ambiente. Construções sustentáveis. MMA Brasilia, 2015. http://www.mma.gov.br/cidades-sustentaveis/urbanismo-sustentavel/constru\%C3\% 
A7\%C3\%A3o-sustent\%C3\%A1vel

[2] Ding, G.K.C. (2008) Sustainable Construction-The Role of Environmental Assessment Tools. Journal of Environmental Management, 86, 451-464.

https://doi.org/10.1016/j.jenvman.2006.12.025

[3] Vechi, N.R.G, Gallardo, A.L.C.F. and Teixeira, C.E. (2016) Aspectos ambientais do setor da construção civil: Uma contribuição para a adoção de sistema de gestão ambiental pelas pequenas e médias empresas de prestação de serviços. Sistemas \& Gestão, 11, 7-33. https://doi.org/10.20985/1980-5160.2016.v11n1.733

[4] Brammer, S. and Walker, H. (2011) Sustainable Procurement in the Public Sector: An International Comparative Study. International Journal of Operations \& Production Management, 31, 452-476. https://doi.org/10.1108/01443571111119551

[5] Novis, L.E.M. (2014) Estudo dos Indicadores Ambientais na Construção CivilEstudo de Caso em Quatro Construtoras. UFRJ/Escola Politécnica, Rio de Janeiro.

[6] Roth, C.G. and Garcias, C.M. (2009) Construção Civil e a Degradação Ambiental. Desenvolvimento em Questão. 7, 111-128.

[7] Souza, M.N. (2015) Licitação Sustentável: A administração pública em prol da sustentabilidade ambiental. Ambito Juridico.

http://www.ambito-juridico.com.br/site/index.php?n_link=revista_artigos_leitura\& artigo_id=10603

[8] Stevens, C. (2010) Linking Sustainable Consumption and Production: The Government Role. Natural Resources Fórum, 34, 16-23.

https://doi.org/10.1111/j.1477-8947.2010.01273.x

[9] AES (2008) Principles of Sustainable Procurement, Policy and Procedure Statement. v3, Aurora Energy System, Melbourne.

[10] Defra (2006) Procuring the Future-The Sustainable Procurement Task Force National Action Plan. DEFRA, London.

[11] Mensah, S. and Ameyaw, C. (2014) Barriers to Sustainable Construction in the Ghanaian Construction Industry: Consultants Perspectives. Journal of Sustainable Development, 7, 134-143.

[12] Adjarko, H., Osei-Poku, G. and Ayarkwa, J. (2014) Challenges to the Incorporation of Environmental Sustainability Issues into Construction Procurement at the Local Government Level of Ghana. International Refereed Journal of Engineering and Science, 3, 42-52.

[13] Djokoto, S.D., Dadzie, J. and Ababio, E.O. (2014) Barriers to Sustainable Construction in the Ghanaian Construction Industry: Consultants Perspectives. Journal of Sustainable Development, 7, 134-143. https://doi.org/10.5539/jsd.v7n1p134

[14] Leite, H.F. (2013) Sustentabilidade em empreendimentos imobiliários residenciais: Avaliação dos custos adicionais para o atendimento dos requisitos de certificação ambiental. Escola Politécnica da Universidade de São Paulo, São Paulo.

[15] Sourani, A. and Sohail, M. (2011) Barriers to Addressing Sustainable Construction in Public Procurement Strategies. Proceedings of the Institution of Civil Engineers: Engineering Sustainability, 164, 229-237. https://doi.org/10.1680/ensu.2011.164.4.229

[16] Ayarkwa, J. and Ayirebi-Danso, A.P. (2010) Barriers to Implementation of EMS in Construction Industry in Ghana. International Journal of Engineering Science, 2, 37-45.

[17] Walker, H., Di Sistob, L. and Mcbainc, D. (2008) Drivers and Barriers to Environmental Supply Chain Management Practices: Lessons from the Public and Private Sectors. Journal of Purchasing and Supply Management. 14, 69-85. 
https://doi.org/10.1016/j.pursup.2008.01.007

[18] Chari, F. and Chiriseri, L. (2014) Barriers to Sustainable Procurement in Zimbabwe. Greener Journal of Business and Management Studies, 4, 14-18.

[19] Chin, K.V. (2014) Challenges and Awareness on Sustainable Procurement in the Context of FM in Singapore. Institute of Environmental Design and Engineering, University College London, London.

[20] Faith-Ell, C., Balfors, B. and Folkeson, L. (2006) The Application of Environmental Requirements in Swedish Road Maintenance Contracts. Journal of Cleaner Production, 14, 163-171. https://doi.org/10.1016/j.jclepro.2004.11.004

[21] Hall, M. and Purchase, D. (2006) Building or Bodging? Attitudes to Sustainability in UK Public Sector Housing Construction Development. Sustainable Development, 14, 205-218. https://doi.org/10.1002/sd.265

[22] Milaré, E. (2009) Direito do ambiente. Revista dos Tribunais, São Paulo.

[23] IPEA (2011) Sustentabilidade Ambiental no Brasil: Biodiversidade, economia e bem-estar humano Comunicado. Comunicados do IPEA n 81. Instituto de Pesquisa Econômica Aplicada.

http://www.ipea.gov.br/portal/images/stories/PDFs/comunicado/110222_comunica doipea79.pdf

[24] Speerschneider, K.K. and Bryer, J.M. (2013) Likert: An R Package for Visualizing and Analyzing Likert-Based Items. R User Conference, useR! University of Castilla-La Mancha, Albacete.

[25] Boone, H.N. and Boone, D.A. (2012) Analyzing Likert Data. Journal of Extension, 50, 1-5.

[26] Norman, G. (2010) Likert Scales, Levels of Measurement and the "Laws" of Statistics. Advances in Health Sciences Education, 15, 625-632. https://doi.org/10.1007/s10459-010-9222-y

[27] Carifio, J. and Perla, R. (2008) Resolving the 50 Year Debate around Using and Misusing Likert Scales. Medical Education, 42, 1150-1152. https://doi.org/10.1111/j.1365-2923.2008.03172.x

[28] Clason, D.L. and Dormody, T.J. (1994) Analyzing Data Measured by Individual Likert-Type Items. Journal of Agricultural Education, 35, 31-35.

[29] Sisson, D.V. and Stocker, H.R. (1989) Research Corner: Analyzing and Interpreting Likert-Type Survey Data. Delta Pi Epsilon Journal, 31, 81-85.

[30] Wakita, T., Ueshima, N. and Noguchi, H. (2012) Psychological Distance between Categories in the Likert Scale Comparing Different Numbers of Options. Educational and Psychological Measurement, 72, 533-546. https://doi.org/10.1177/0013164411431162

[31] Cronbach, L.J. (1951) Coefficient Alpha and the Internal Structure of Tests. Psycometrika, 16, 297-334. https://doi.org/10.1007/bf02310555

[32] Martins, L.R.B., Pereira, L.S, Almeida, L.M, Hora, H.R.M. and Costa, H.G.M. (2011) Estudo sobre escala mais adequada em questionários: Um experimento com o modelo de Kano. Vértices, 13, 75-103.

[33] Almeida, D., Santos, M.A.R. and Costa, A.F.B. (2010) Aplicação do coeficiente Alfa de Cronbach nos resultados de um questionário para avaliação de desempenho da saúde pública. XXX Encontro Nacional de Engenharia de Produção, São Carlos.

[34] Freitas, A.L.P. and Rodrigues, S.G. (2005) A avaliação da confiabilidade de questionários: Uma análise utilizando o coeficiente alfa de Cronbach. XII SIMPEP, Bauru.

[35] Kats, G. (2010) Greening Our Built World: Costs, Benefits, and Strategies. Island 
Press, Washington DC.

[36] CBCS (2007) Sustentabilidade na Construção. Conselho Brasileiro de Construção Sustentável.

http://www.cbcs.org.br/website/noticia/show.asp?npgCode=DBC0153A-072A-4A43 -BB0C-2BA2E88BEBAE

[37] European Environment Agency (2016) About Environmental Technology. http://www.eea.europa.eu/pt/themes/technology/about

[38] Redin, E. and Silveira, P.R.C. (2012) The Brazilian Environmental Policy: Limitations and Challenges. Cadernos de Pesquisa Interdisciplinar em Ciências Humanas, 13, 163-188.

[39] LIMA, G.F.C. (2011) A institucionalização das políticas e da gestão ambiental no Brasil: Avanços, obstáculos e contradições. Desenvolvimento e Meio Ambiente, 23, 121-132. https://doi.org/10.5380/dma.v23i0.20948

[40] Vaz, M.V.N. (2013) Empreendimento sustentável: Requisitos legais, requisitos voluntários, benefícios legais. Universidade Federal de Ouro Preto, Ouro Preto.

[41] Pedro, A.F.P. (2016) O licenciamento ambiental e sua sustentabilidade no Brasil. TECHOJE. http://www.techoje.com.br/site/techoje/categoria/detalhe_artigo/778

Submit or recommend next manuscript to SCIRP and we will provide best service for you:

Accepting pre-submission inquiries through Email, Facebook, LinkedIn, Twitter, etc. A wide selection of journals (inclusive of 9 subjects, more than 200 journals)

Providing 24-hour high-quality service

User-friendly online submission system

Fair and swift peer-review system

Efficient typesetting and proofreading procedure

Display of the result of downloads and visits, as well as the number of cited articles

Maximum dissemination of your research work

Submit your manuscript at: http://papersubmission.scirp.org/

Or contact ojce@scirp.org 